\title{
A Comparison of Bioactive Glass Scaffolds Fabricated by Robocasting from Powders Made by Sol-Gel and Melt-Quenching Methods
}

\author{
Basam A. E. Ben-Arfa * and Robert C. Pullar *(D) \\ Department of Materials and Ceramic Engineering/CICECO-Aveiro Institute of Materials, University of Aveiro, \\ 3810-193 Aveiro, Portugal \\ * Correspondence: basam@ua.pt (B.A.E.B.-A.); rpullar@ua.pt (R.C.P.)
}

Received: 26 February 2020; Accepted: 16 May 2020; Published: 21 May 2020

check for updates

\begin{abstract}
Bioactive glass scaffolds are used in bone and tissue biomedical implants, and there is great interest in their fabrication by additive manufacturing/3D printing techniques, such as robocasting. Scaffolds need to be macroporous with voids $\geq 100 \mu \mathrm{m}$ to allow cell growth and vascularization, biocompatible and bioactive, with mechanical properties matching the host tissue (cancellous bone for bone implants), and able to dissolve/resorb over time. Most bioactive glasses are based on silica to form the glass network, with calcium and phosphorous content for new bone growth, and a glass modifier such as sodium, the best known being $45 \mathrm{~S} 5$ Bioglass ${ }^{\circledR}$. $45 \mathrm{~S} 5$ scaffolds were first robocast in 2013 from melt-quenched glass powder. Sol-gel-synthesized bioactive glasses have potential advantages over melt-produced glasses (e.g., greater porosity and bioactivity), but until recently were never robocast as scaffolds, due to inherent problems, until 2019 when high-silica-content sol-gel bioactive glasses (HSSGG) were robocast for the first time. In this review, we look at the sintering, porosity, bioactivity, biocompatibility, and mechanical properties of robocast sol-gel bioactive glass scaffolds and compare them to the reported results for robocast melt-quench-synthesized 45S5 Bioglass ${ }^{\circledR}$ scaffolds. The discussion includes formulation of the printing paste/ink and the effects of variations in scaffold morphology and inorganic additives/dopants.
\end{abstract}

Keywords: robocasting; bioactive glass; scaffold; sol-gel; $45 \mathrm{~S} 5$ Bioglass ${ }^{\circledR}$; biomaterials; biomedical implants

\section{Introduction}

Robocasting is an additive manufacturing or 3D printing technique, in which designed 3D structures are built layer-by-layer by extruding a continuous filament of a paste/printing ink from a nozzle, guided by an automated computerized system (Figure 1) [1]. It was initially developed at Sandia National Laboratories in 1996 to fabricate free-formed objects with a slurry containing low levels of binder [2,3], and was rapidly adopted to manufacture periodic 3D ceramic structures [4]. Robocasting is a particularly promising technique for bone scaffold fabrication as the scaffold can be designed to specifically mimic and replace an injured or missing part of the body as a "bespoke" implant [5], with improved mechanical properties compared to older fabrication techniques [6]. In robocasting, the ink is extruded from a nozzle to construct 3D structures. The extrusion speed and scaffold shape and size are all controlled by a computer-aided design-computer-aided manufacturing (CAD-CAM) [7] model, deposited layer-by-layer as a 3D structure [8] from an ink or paste formulated from a powder with liquid and polymeric additives. 

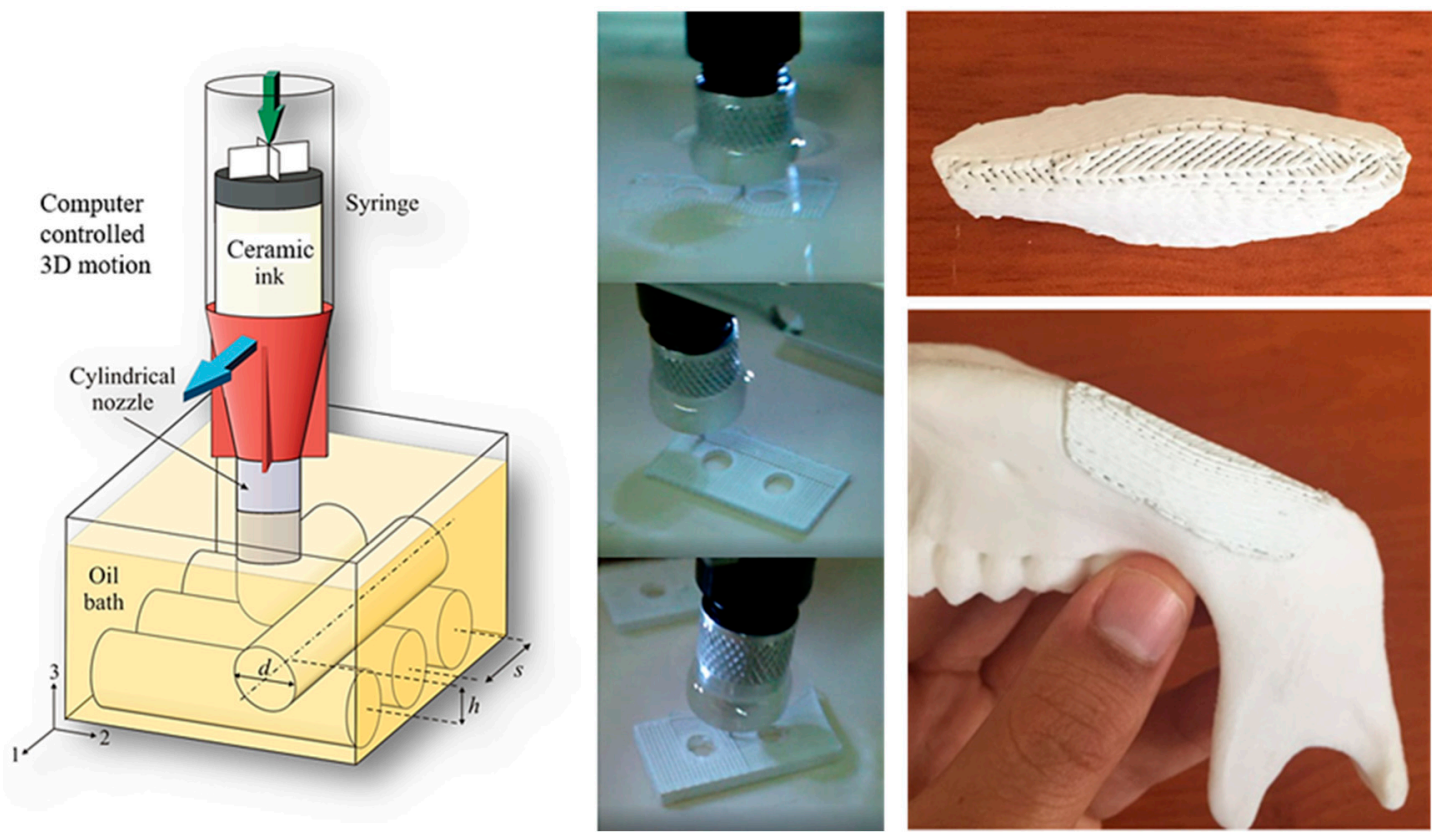

Figure 1. Schematic illustration and in-situ images of the robocasting process within an oil bath, and an example of a sintered scaffold for human mandibular defect reconstruction. [https://www.euroceram. org/en/technologies/material-extrusion/robocasting-direct-ink-writing.html, accessed on January 2020].

Robocasting has been used to produce porous scaffolds of calcium phosphate bioceramics for biomedical bone implants since the beginning of the 21st century $[9,10]$, but $\mathrm{SiO}_{2}-\mathrm{CaO}-\mathrm{P}_{2} \mathrm{O}_{5}$-based bioactive glasses have only been robocast in the last decade [11-15]. The best known example of a bioactive glass is Bioglass ${ }^{\circledR}$ (45S5) [16], discovered by Hench and co-workers in 1969 [17]. $45 S 5$ is known by its commercial brands Bioglass ${ }^{\circledR}$, PerioGlas ${ }^{\circledR}$ and NovaBone ${ }^{\circledR}$ in particulate form, and NovaMin ${ }^{\circledR}$ in toothpaste, and it contains $45 \mathrm{wt} \% \mathrm{SiO}_{2}, 24.5 \mathrm{wt} \% \mathrm{CaO}, 24.5 \mathrm{wt} \% \mathrm{Na}_{2} \mathrm{O}$, and $6.0 \mathrm{wt} \%$ $\mathrm{P}_{2} \mathrm{O}_{5}$, with a $\mathrm{Ca} / \mathrm{P}$ ratio of $\sim 5$ [17]. This high sodium content (as a glass modifier) means it is soft in comparison to other glasses and can be easily machined or ground to a powder [18], but it has to be stored in a dry environment as it readily absorbs and reacts with moisture. It has also proven difficult to fabricate as porous 3D scaffolds and sinter into a dense material, as it crystallizes at a relatively low temperature, with a small sintering window [19]. Indeed, it was not robocast successfully until 2013 [11].

An alternative preparation method to melt-quenching, which has been greatly explored for the synthesis of bioactive glasses, is sol-gel [20]. Apart from the potential to avoid unwanted crystallization during synthesis, one of the great advantages of sol-gel bioactive glasses is that the glass powder can be much more porous than that produced from a melt. This should result in a greater degree of bioactivity in any resulting implant. For example, the ternary $58 \mathrm{~S}$ glass (containing $60 \mathrm{wt} \% \mathrm{SiO}_{2}$, $36 \mathrm{wt} \% \mathrm{CaO}$, and $4 \mathrm{wt} \% \mathrm{P}_{2} \mathrm{O}_{5}$ ), when produced by the sol-gel process, had a much greater specific surface area than melt-derived $45 \mathrm{~S} 5$ (79 vs. $2.7 \mathrm{~m}^{2} / \mathrm{g}$, respectively) [20]. Hench used sol-gel about two decades after its initial discovery to prepare $45 \mathrm{~S} 5$ glass, which enhanced both its surface morphology and bioactivity [21,22], but this sol-gel $45 \mathrm{~S} 5$ has never been successfully robocast to date. This is because sol-gel-derived bioactive glasses have proven problematic for robocasting, as the high specific surface area and porous structure of the glass powder results in absorption of a significant portion of the dispersing liquid from the suspension, impeding paste/ink formulation and greatly reducing printability. The first robocast sol-gel-synthesized bioactive glass scaffolds were only reported in 2019 [23,24]. These were of a quaternary high-silica sol-gel glass (HSSGG) with a low sodium composition of $64.4 \mathrm{wt} \% \mathrm{SiO}_{2}, 4.9 \mathrm{wt} \% \mathrm{Na}_{2} \mathrm{O}, 21.5 \mathrm{wt} \% \mathrm{CaO}$, and $9.1 \mathrm{wt} \% \mathrm{P}_{2} \mathrm{O}_{5}$ [24]. This glass was synthesized by an innovative rapid sol-gel synthesis route, which produced a bioactive glass powder 
in about $1 \mathrm{~h}-$ more than one hundred times faster than the quickest reported standard sol-gel methods, which require lengthy drying and ageing processes of several days to weeks [25].

\section{Bone Scaffolds}

Scaffolds for bone regeneration must contain interconnected pores/voids on the scale of $100 \mu \mathrm{m}$ or more to enable cell seeding, proliferation, and vascularization (formation of blood vessels), which results in the formation of new bone [26]. The scaffold must be strong enough to replace the bone temporarily while providing a suitable substrate for cell attachment and proliferation, and it should also slowly degrade (be resorbable) and be replaced as the new tissue grows [27]. Therefore, it must be made of a bioactive and biocompatible material, which allows precipitation/crystallization of the calcium phosphate minerals (typically hydroxyapatite, $\mathrm{Ca}_{10}\left(\mathrm{PO}_{4}\right)_{6}(\mathrm{OH})_{2}, \mathrm{HAp}$ ), which enhances the bonding between the implant and the bone, ensuring good fixation and preventing micro-movements and implant failure, and it cannot be cytotoxic to the cells [28,29].

Scaffolds are usually formed in what is known as a "wood pile" or "log-cabin" structure of extruded struts, with voids between them (Figure 2). This forms an extracellular matrix in which the cells can grow and function, and this also helps define the structural properties of the resultant tissue. The scaffold serves as a temporary template to support/guide the growth of new tissue to restore normal function, but during the healing process, the scaffold should also gradually degrade to be replaced by new cells as they grow and proliferate to regenerate new tissue [30].

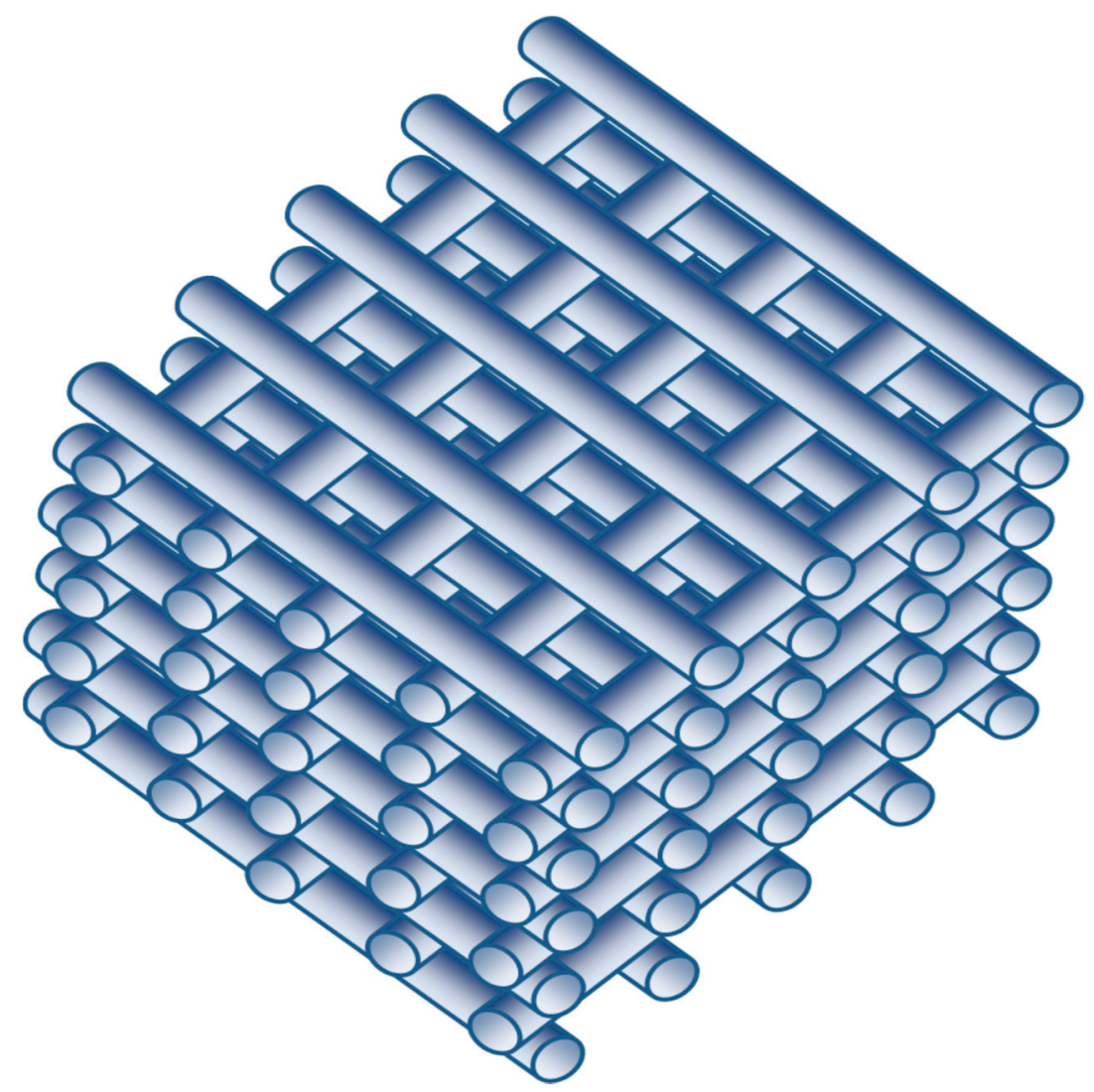

Figure 2. The typical "wood pile" or "log-cabin" scaffold structure.

As the 3D shapes are fabricated by the extrusion of a paste from a nozzle layer-by-layer, this paste, sometimes also called a printing ink, must have optimized rheological properties such as a high viscosity at zero shear and thinning behavior at applied shear. It must also have excellent shape retention capabilities, such as high elastic modulus and yield stress, after deposition and throughout the printing, drying, and sintering steps [31]. The extruded filament must retain its shape and resist 
the exerted loads of the subsequent layers printed above it, and casting (extrusion) can either take place in air or in a liquid medium to allow homogeneous drying. In the case of a robocast glass, the green scaffold must be dried at room temperature and then heated or sintered gradually to eliminate any organic additives to produce the final form.

To function well, a scaffold should have:

1. Biocompatibility: It must be non-cytotoxic and tissue-compatible, allowing the necessary cells to attach, differentiate, and proliferate. Any dissolved materials from the scaffold must not have any toxic/infla $\mu$ atory influence on cells and tissues, and the body should be able to get rid of these degraded products without any side-effects.

2. Bioactivity: It must actively interact with body fluids and tissues to function, for example, crystallize new calcium phosphate minerals for bone growth. A scaffold can also be used to influence cell morphology and position, deliver growth factors to speed regeneration, or to release or trap biomolecules in a regulated manner.

3. Biodegradability: It must degrade with time (weeks/months) after implantation as it is gradually replaced by new generative tissues. It should degrade at a rate similar to that of the new tissue growth.

4. Suitable morphology and structure: It must have sufficient void/pore volume for new tissue formation and growth, needing large interconnected macropores $>50-100 \mu \mathrm{m}$ to permit cells to infiltrate easily into the scaffold core, and allow any waste to diffuse out of it. Ideally, it should also have a hierarchical degree of porosity within the scaffold struts in the size range of 2-50 $\mu \mathrm{m}$ (mesopores) to facilitate cell anchorage and proliferation, permit vascularisation, and enable nutrient/metabolite transport without compromising mechanical stability.

5. Similar mechanical properties to the host tissue: It must withstand the exerted loads, but with no stress shielding effect from a mechanical mismatch, which can cause bone resorption and implant failure. Cells have shown an ability to be sensitive to the stiffness of the scaffold, which can affect cell adhesion [32] and differentiation [33], and the scaffold needs to maintain overall mechanical integrity during the new bone formation and resorption processes $[27,34]$.

\section{Bioactive Glass}

When implanted in the body, bioactive glasses such as $45 S 5$ react with body fluid, exchanging the $\mathrm{Na}^{+}$and $\mathrm{Ca}^{2+}$ ions on their surface with $\mathrm{H}^{+}$ions in the fluid to hydrolyze and form $\mathrm{Si}-\mathrm{OH}$ bonds, accompanied by an initial increase in $\mathrm{pH}$. This creates $\mathrm{more} \mathrm{OH}^{-}$ions at the surface, which go on to break $\mathrm{Si}-\mathrm{O}-\mathrm{Si}$ bonds (forming more $\mathrm{Si}-\mathrm{OH}$ bonds), dissolving the silica glass network. The $\mathrm{Si}-\mathrm{OH}$ groups at the surface then recondense and re-polymerize, reforming new Si-O-Si bonds as a new silica-gel layer on the surface, which will now have a very low $\mathrm{Na}^{+}$content. At the same time, $\mathrm{Ca}^{2+}$ and $\mathrm{PO}_{4}{ }^{3-}$ ions from both the bioactive glass and body fluid form a calcium phosphate layer on top of the silica layer. This also incorporates $\mathrm{CO}_{3}{ }^{2-}$ and $\mathrm{OH}^{-}$ions from the body fluid, crystallizing a hydroxycarbonate apatite $\left(\mathrm{Ca}_{10-x-y / 2}\left(\mathrm{HPO}_{4}\right)_{x}\left(\mathrm{PO}_{4}\right)_{6-x-y}\left(\mathrm{CO}_{3}\right)_{y}(\mathrm{OH})_{2-x}, \mathrm{HCAp}\right)$ layer, which, in a few hours, begins to convert to crystalline HAp, forming bone-like material [35]. Over the following weeks, M2 macrophages (which promote wound healing) attract mesenchymal stem cells and osteoprogenitor cells, which, in turn, differentiate to become bone tissue cells such as osteoblasts. Other bone components such as collagen also form, and they combine with HAp nanocrystals to form new bone, as the silica bioactive glass implant degrades, dissolves, and resorbs [36].

\subsection{Bioactive Glass Synthesis Methods}

Bioactive glasses are mainly produced by two techniques: Sol-gel [25,37-39] and melt- quenching methods [39-41]. Hench was a pioneer in using both of these techniques for bioactive glass synthesis. He initially used the melt-quenching technique in 1969 [17] to prepare 45S5 and used sol-gel about 
twenty years later to prepare the same glass, but enhancing the surface morphology and bioactivity [22]. Both methods are now commonly adopted for producing bioactive glasses.

\subsubsection{Melt-Quenching Method}

In the melt-quenching method, glass is obtained by mixing, homogenizing, calcining, and fusing glass precursors such as oxides or carbonates above $1300-1500^{\circ} \mathrm{C}$. After heating the mixed precursors in a platinum crucible, the melt is quenched (rapidly cooled to avoid crystallization) in cold water to obtain a glass frit, or cast/quenched in graphite molds to obtain bulk glasses [19,40,41]. This is the method typically used to obtain Bioglass ${ }^{\circledR} 45 \mathrm{~S} 5$ and other commercial bioactive glasses.

\subsubsection{Sol-Gel Method}

In the sol-gel method, an aqueous solution of the precursors (alkoxides and/or metal salts) is stirred for hydrolysis and condensation, resulting in a clear sol. This is then dried and aged for a long period of time, often weeks [25], followed by calcination to obtain glass granules or monolithic shapes [22,42]. Sol-gel-derived bioactive glasses have high porosity in comparison to those made from melt-quenching, which generally improves their bioactivity. The minimum ideal total porosity for good bone growth in a scaffold is generally accepted to be $~ 50 \%$ [43]. The long aging and drying periods can be problematic and lead to unwanted crystallization, which needs to be minimized, and this long process is very much a rate limiting step for the sol-gel method.

\subsubsection{Rapid Sol-Gel Method}

For the reasons given above, Ben-Arfa et al. developed an innovative rapid sol-gel synthesis route for a quaternary bioactive glass system, which can produce a bioactive glass powder in about $1 \mathrm{~h}$-more than one hundred times faster than the quickest reported standard sol-gel methods [25]. This involves the sequential combination of the bioactive glass precursors in an aqueous solution, followed by rapid drying on a rotary evaporator, avoiding any ageing (Figure 3). This was shown to produce stabilized (devitrified) bioactive glasses with virtually identical properties, and enhanced bioactivity, compared to those made by conventional routes.

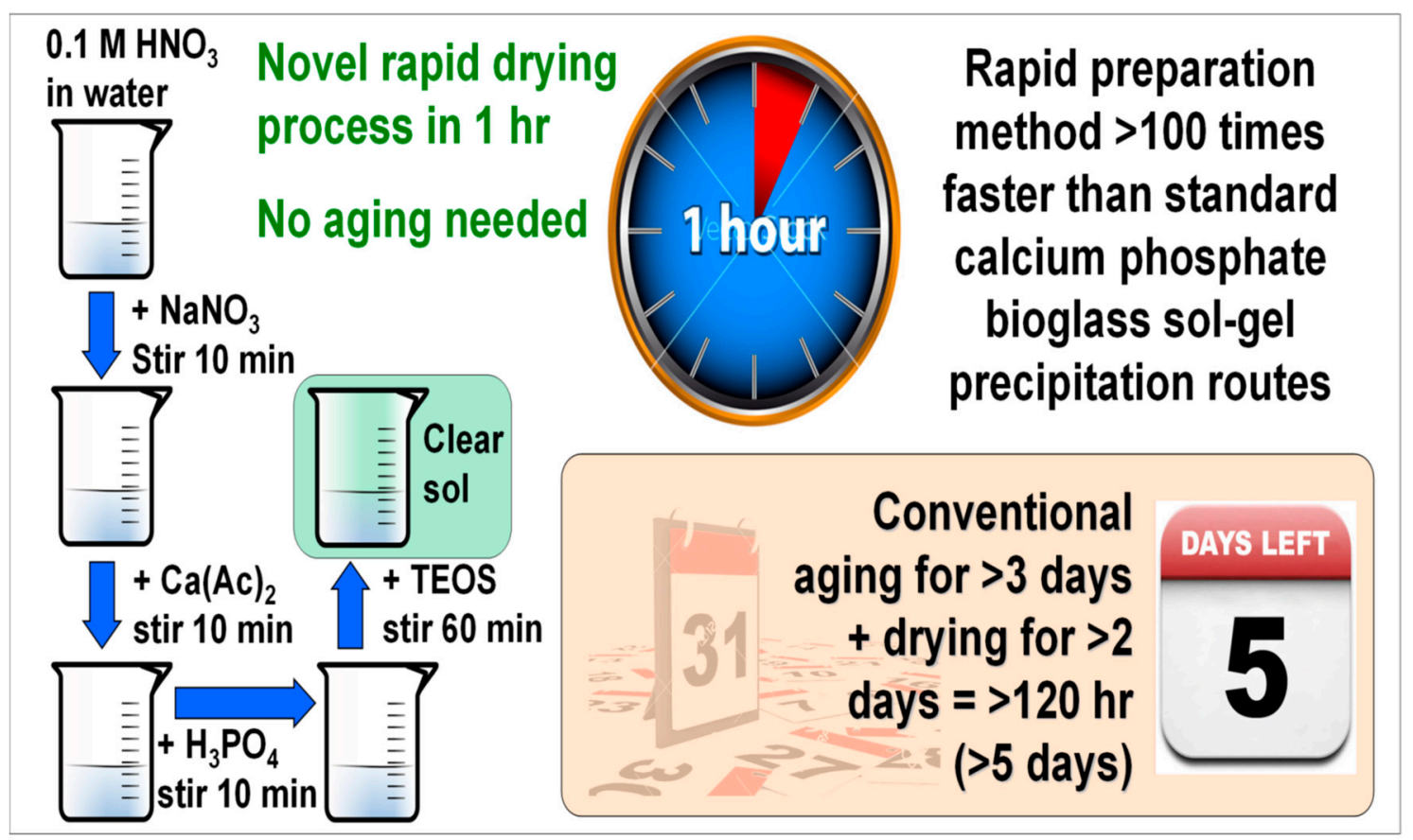

Figure 3. A depiction of the rapid sol-gel bioactive glass synthesis route developed by Ben-Arfa et al. [25]. 


\section{Robocasting and Printing Paste/Ink Preparation}

Many materials have been used to robocast scaffolds including calcium phosphate bioceramics [43-45] and polymer/ceramic composites [46,47]. However, the robocasting of bioactive glass scaffolds proved to be more difficult, even when using melt-quenched glass frit powders, which themselves exhibit less porosity than sol-gel bioactive glasses. The high porosity of sol-gel-derived bioactive glass powders created even greater difficulties in the paste preparation process, as a significant part of the dispersing liquid is absorbed and trapped in the pores, reducing the flow and stability of the paste/ink. Due to these issues, there have been far fewer reports on the robocasting of bioactive glass scaffolds compared to bioceramics, and this was limited entirely to glass compositions prepared by melt-quenching [48,49], until the successful robocasting of sol-gel-derived bioactive glass scaffolds was reported for the first time in 2019 by Ben-Arfa et al. [23,24].

Essential for the successful fabrication of scaffolds by robocasting are factors such as the simplicity of ink preparation, printability, and the ability of the glass composition to sinter [15]. The well-known $45 \mathrm{~S} 5$ Bioglass ${ }^{\circledR}$ does not meet several of these requirements, as the high degree of leaching of $\mathrm{Na}^{+}$and the abrupt increase in $\mathrm{pH}$ hinders an efficient dispersion, and the successful preparation of robocasting pastes of melt-quenched $45 S 5$ glasses was only quite recently achieved [15,48]. Much of the work on the robocasting of glass scaffolds was carried out using less soluble and low-alkali glasses with broader sintering windows, such as the $13-93$ composition $\left(53 \mathrm{wt} \% \mathrm{SiO}_{2}, 6 \mathrm{wt} \% \mathrm{Na}_{2} \mathrm{O}, 12 \mathrm{wt} \% \mathrm{~K}_{2} \mathrm{O}\right.$, $5 \mathrm{wt} \% \mathrm{MgO}, 20 \mathrm{wt} \% \mathrm{CaO}, 4 \mathrm{wt} \% \mathrm{P}_{2} \mathrm{O}_{5}$ ) [49], but any gains in sinterability and mechanical properties were achieved at the expense of poorer bioactivity [8]. Indeed, despite over 40 years of research on bioactive glasses by many groups since Hench's invention of 45S5, no other bioactive glass composition has been found to have significantly better biological properties than the original Bioglass ${ }^{\circledR} 45 \mathrm{~S} 5$ composition [19].

The formulation of inks/pastes for robocasting from bioactive sol-gel glasses is even more difficult due to their higher specific surface area and more porous structure, which, while improving bioactivity, has until recently constituted the main barrier to using them in robocasting.

A high-quality scaffold must have well-defined and interconnected pores/voids to allow good vascularization, and it must be mechanically stable and fully capable of supporting its own weight during robocasting, drying, sintering, and use without evident shape deformation or the overlapping of layers, but with strong adhesion between adjacent layers. The strength of cancellous bone (also known as trabecular bone, the spongy interior part) is between 2 and $12 \mathrm{MPa}$ [50], so a bone scaffold should ideally be in this range as well. This is important, as one of the major causes of postoperative bone implant failure is a stiffness mismatch between the implanted biomaterial and surrounding bone tissue. $45 \mathrm{~S} 5$ robocast scaffolds are typically within this range, but the mechanical properties of the denser low-sodium-glass robocast scaffolds such as 13-93 are too high for compatibility with cancellous bone. 13-93 scaffolds have been measured as having a compressive strength between 48 and $142 \mathrm{MPa}[8,12,14]$, in the region of cortical (hard exterior) bone (100-150 MPa) [50], which is less useful for implants and much greater than the values for cancellous bone, resulting in a mismatch. For these reasons, this review will focus on comparing $45 \mathrm{~S} 5$ glass robocast scaffolds with sol-gel glass robocast scaffolds.

Throughout the rest of this review, we will use the word "voids" to describe the macropores between the struts from robocasting to avoid confusion with any microporosity within the struts themselves.

\subsection{Powder Milling}

Milling, comminution, and pulverization are interchangeable phrases for the mechanical reduction in particle size of the glass powder. Powder milling is a very important part of the successful formulation of the paste in robocasting, particularly for bioactive glasses for robocasting, which justifies renewed investigations of the powder milling process. The powder can be subjected to wet or dry milling, although wet milling usually proves more effective and is recommended when agglomeration between particles is induced due to their high surface energy [51]. The decrease in particle size taking place 
during milling results from accumulated stresses induced in the particles from the applied mechanical energy. This causes cracks that propagate and break the particle [52].

Various important parameters need to be taken into account when performing wet milling, such as solids loading (liquid-to-powder ratio (LPR)), the balls-to-powder ratio (BPR) [53], and the speed and type of milling machine [54]. Elevated heat treatment temperatures (HTT) can result in the formation of hard agglomerates that are difficult to destroy with milling. The individual and mutual influences of HTT and BPR on the wet-milling performance and morphology of the powders produced have been studied and well documented [55].

Although powder milling is of key importance in the formulation of the printing ink, few details are usually given of the milling conditions/parameters in articles published on the robocasting of bioactive glasses produced by melt-quenching, often just stating the mill type/model and milling time. Some research groups employed exaggerated milling times of the glass continuously for several days, neglecting the effect of contamination from the milling balls and milling jars, as in the case of wet milling an alkali-free bioactive glass for $2 \mathrm{~h}$ in a planetary mill, then 6 days in a ball mill, followed by attrition milling for time periods from 2 and $12 \mathrm{~h}$ (158 h in total, in ethanol) [56]. Such a long milling time will almost certainly lead to contamination of the glass, and involves high costs of energy and time. On the other hand, it was demonstrated by Ben Arfa et al. [31,55] that a simple, cheap rapid milling machine was sufficient to mill glass granules for robocasting in $2 \mathrm{~h}$, and that highly expensive and sophisticated milling machines (attrition mills, planetary mills) are not necessary. These authors also used ethanol as the milling medium and, employing a BPR of 10 and LPR of 1.5, reduced the milling time further to just $1 \mathrm{~h}$ to prepare a sol-gel glass robocasting paste [23,24].

A detailed experimental procedure for different milling conditions for 13-93 glass was fully described in [8], and these authors also compared the effects of different milling media (water/ethanol) on the subsequent mechanical and biomineralization performance of the robocast 13-93 scaffolds [57]. The results revealed that wet milling using ethanol led to scaffolds with higher bioactivity and better mechanical properties than using water as milling media. The effects of wet-milling parameters and calcination temperature on the final powder morphology of the HSSGG sol-gel glass were also studied in detail [55], and it was found that BPR has an important influence on the final particle size distribution of the powders, as shown in Figure 4, with higher BPR values generally resulting in a smaller particle size and lower size distribution. A narrow particle size distribution is generally preferable in ink formulation to achieve a good dispersion, as, with large distributions, fine particles will be dispersed while the coarser ones will tend to sediment.

On the other hand, pore volume and powder morphology were found to be mostly determined by variations in calcination temperature (Figure 5) [55]. These are important parameters, as an increase in pore volume will lead to the absorption of a larger fraction of the dispersion solution, effectively "freezing" the motion of particles and their flow. The availability of open, small-volume pores is a good attribute for the easier preparation of a glass suspension suitable for robocasting. As Figure 5 shows, heating sol-gel HSSGG to $800^{\circ} \mathrm{C}$ was sufficient to obtain a glass powder with pore morphology and reduced the pore volume suitable for ink preparation for robocasting. 

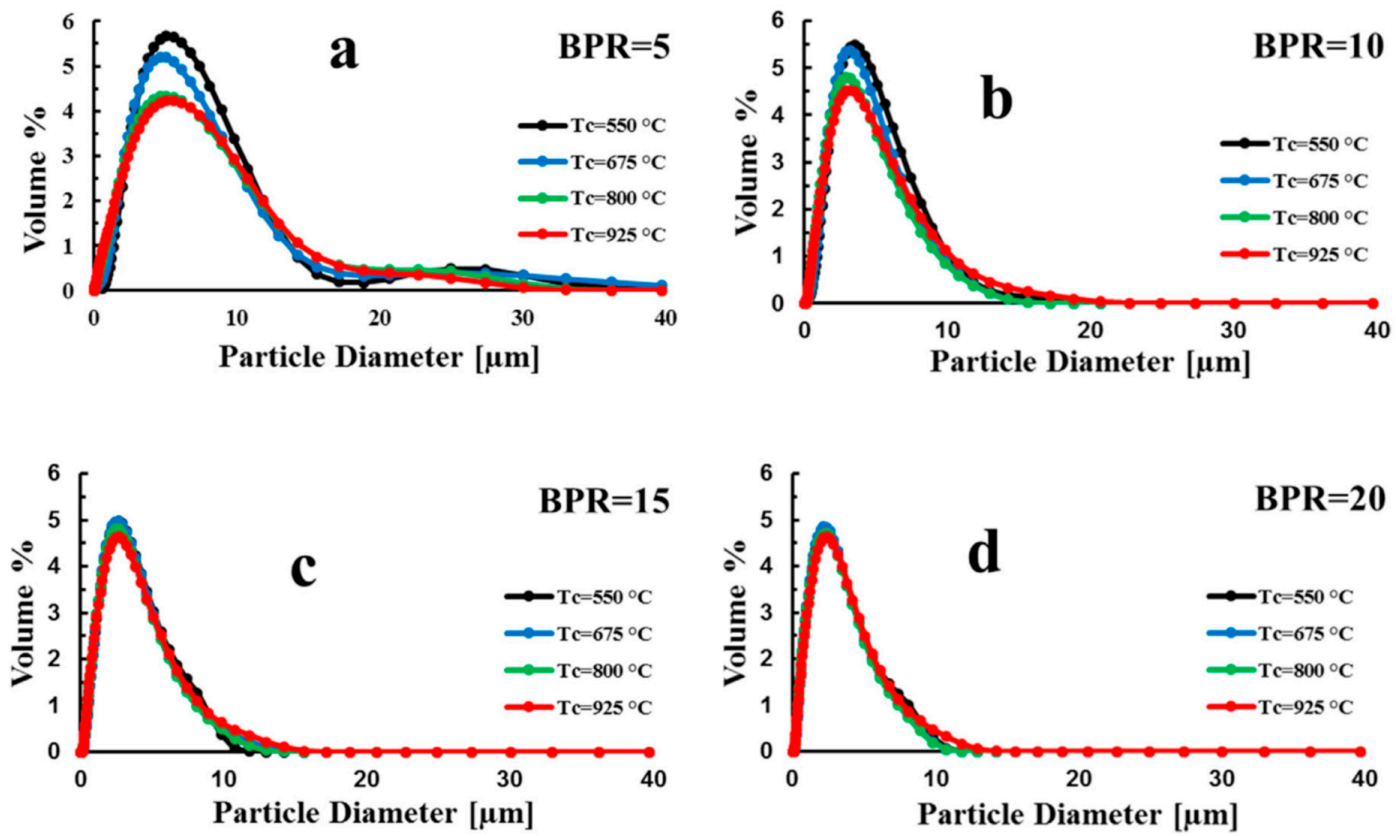

Figure 4. Particle size distributions of the bioactive sol-gel glass powders heat-treated at different temperatures followed by wet-ball milling in ethanol under given values of balls-to-powder ratio (BPR): (a) 5; (b) 10; (c) 15; (d) 20. Reproduced with permission from [55], Copyright Elsevier Ltd. and Techna Group S.r.l., 2018.
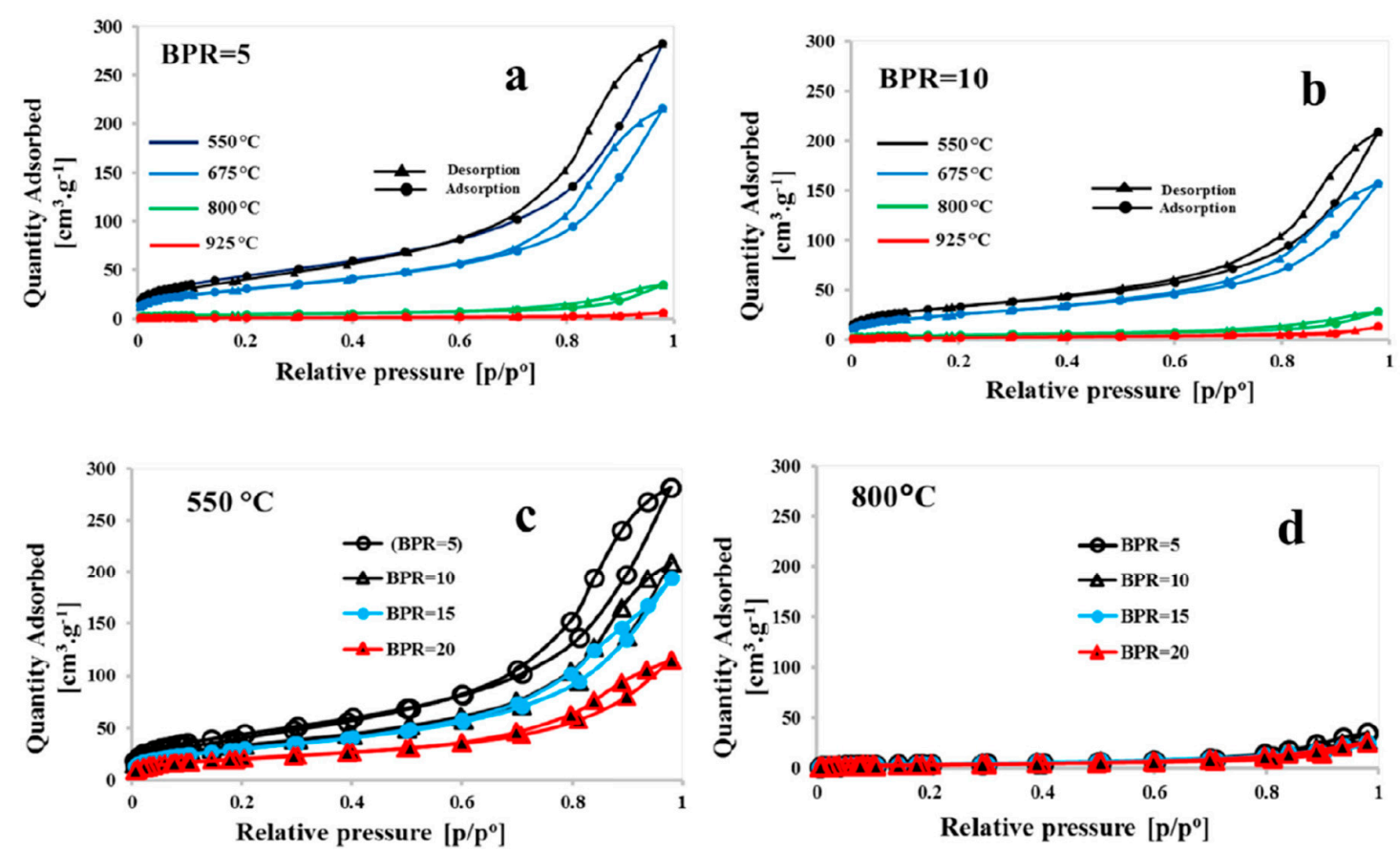

Figure 5. Effects of the processing parameters on the nitrogen sorption isotherms for the bioactive sol-gel glass powders: (a,b) Comparison of two BPRs (5 and 10) used in wet-ball milling in ethanol for samples heat-treated at different temperatures $\left(550,675,800,925^{\circ} \mathrm{C}\right) ;(\mathbf{c}, \mathbf{d})$ comparison of two heat treatment temperatures for powders wet-ball milling in ethanol under different BPR values $(5,10,15$, 20). Reproduced with permission from [55], Copyright Elsevier Ltd. and Techna Group S.r.l., 2018. 


\subsection{Paste Formulation and Preparation}

High-solids loading pastes are recommended in order to reduce the shrinkage of the final sintered scaffold, and values of up to $45 \mathrm{vol} \%$ solids loading have been achieved in robocast bioactive glass pastes. Additives are also an important constituent in the recipe of paste formulation. However, it is preferred to use a very small amount of additive in paste preparation to facilitate their elimination in the post-treatment process. The additives play two significant roles in paste formulation, providing pseudoplastic behavior that promotes paste flowability, and aiding the shape retention and providing resistance to the loads of subsequent layers during and after robocasting. The paste must not contain air bubbles or agglomerations of powder, as the air will result in an irregular, discontinuous extrusion, whereas agglomerates tend to block the nozzle and prevent extrusion. Moreover, the paste must exhibit relatively high viscosity at zero shear stress, and thinning behavior at high shear rates, to ensure the extrusion of the paste from the nozzle [58].

Solids loading is the fractional volume of the solids phase to the total volume of powder and liquid forming the paste [59], the liquid being removed during the drying process. A high solids loading significantly increases the viscosity of the paste, as well as the mechanical properties of the green body and the final sintered scaffold [60]. The glass synthesis method used does not present a great change in the maximum solids loading, with a narrow variation in range of between 35 and 45 vol\% for 45S5 [15,48] and HSSGG robocast glasses [23,24], reflecting the need for a reasonably high solids loading value for a successful robocasting glass paste/ink.

In general, the paste is formulated from a mixture of glass powder, water, and additives such as dispersants, thickeners (binder), and coagulants. Dispersants are polymers used for steric stabilization (surface active agents-surfactants). They are added to aqueous suspensions to be adsorbed on the powder particle surfaces to overcome the Van der Waals interparticle attractive forces and prevent aggregation, enabling the printability of the paste by robocasting. Binders/thickeners/plasticizers are polymers with high molecular weight and are added to increase the viscosity of the suspension to manifest flow behavior, e.g., hydroxyl propyl methylcellulose. Coagulants are also types of polymers that act as physical glue, providing resistance to the external forces exerted on the extruded struts due to the load of the subsequent layer above. Such mixtures were used in the early robocasting of bioactive glasses, but these days, a single additive is mostly used, such as carboxymethyl cellulose (CMC) $[23,24,48]$ or Pluronic F-127 [8,12], as a combined dispersant, plasticizer, and coagulant. The use of a single additive enables a fast and easy process, especially in the case of $\mathrm{CMC}$, which can be used at room temperature, whereas Pluronic F-127 needs a non-ambient temperature to prepare the suspension.

An example of the effects of BPR and calcination temperature of the glass powder on the rheological properties of a robocasting paste, in this case, for sol-gel HSSGG printing inks with 25 and $40 \mathrm{vol} \%$ solids loading, is shown in Figure 6 [31]. Ideally, both a reasonably high viscosity at zero shear stress followed by a gradual decrease in the viscosity (shear thinning behavior) with increased shear rate, and a stable elastic modulus of $\sim 1 \mathrm{MPa}$ throughout the viscoelastic region, are required features for an ink suitable for robocasting. 

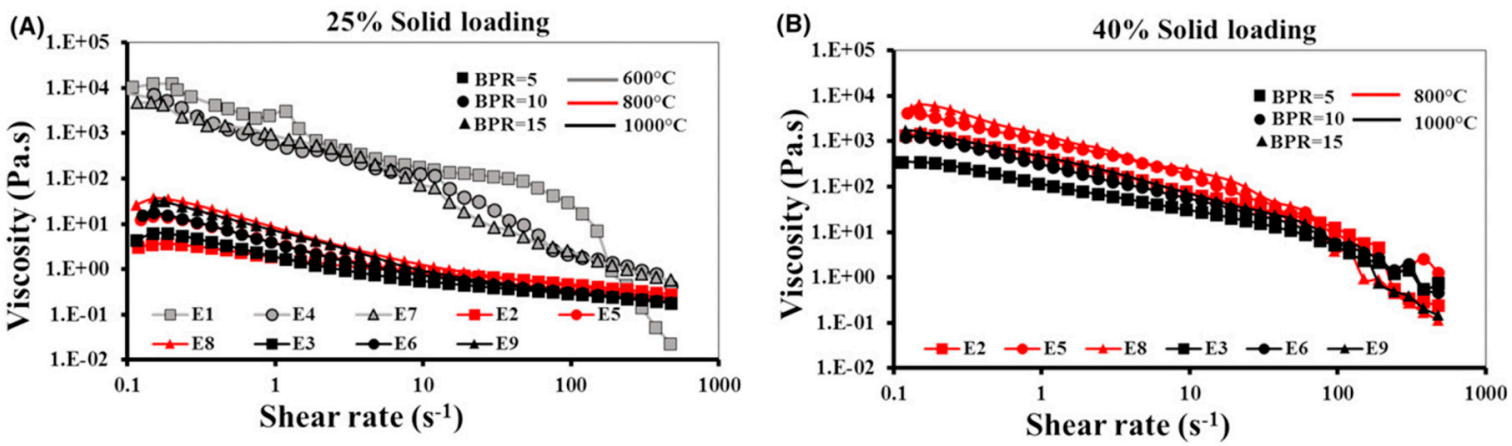

$25 \%$ Solid loading
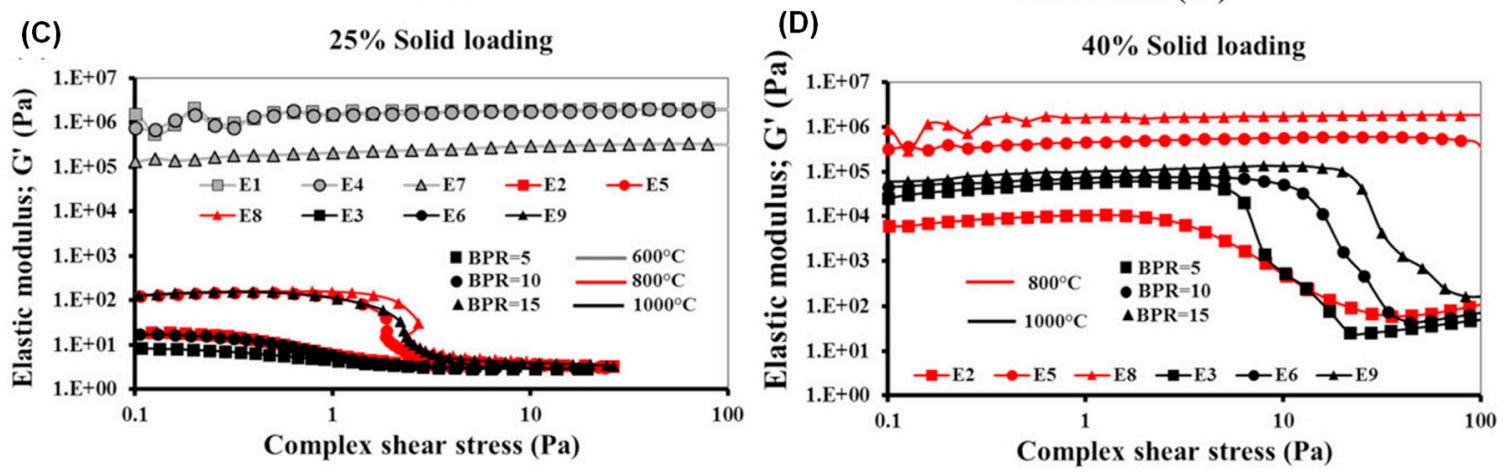

Figure 6. Effects of the processing parameters on the rheological properties of the bioactive glass suspensions. The viscosity behavior of $25 \% \mathrm{SL}$ (A) and $40 \% \mathrm{SL}$ (B) and the viscoelastic properties of the paste at 25\% SL (C) and 40\% SL (D). Reproduced with permission from [31], Copyright the American Ceramic Society, 2018.

\section{Glass-Melt-Synthesized Bioglass ${ }^{\circledR}$ Robocast Scaffolds}

$45 \mathrm{~S} 5$ was first robocast in 2013 by Eqtesadi et al. [15] with a solids loading of $45 \mathrm{vol} \%$, and sintered at $1000{ }^{\circ} \mathrm{C} / 1 \mathrm{~h}$. The scaffolds had $\sim 200 \mu \mathrm{m}$ struts and $\sim 100 \times 250 \mu \mathrm{m}$ rectangular voids, and were robocast in a variety of geometries and up to 60 layers deep. They had a total porosity of $63 \%$ (from an initial macroporosity of 52\%) and compressive strength of $13 \mathrm{MPa}$, stated to be vastly superior to previously reported values for 45S5 scaffolds made by lithography, although they were less porous than scaffolds made by foam replication.

A very detailed paper on the sintering of $45 \mathrm{~S} 5$ robocast scaffolds from a melt-derived glass was published by Eqtesadi et al. in 2014 [48]. TGA/DTA measurements on the as-fabricated scaffold showed a weight loss of $\sim 10 \%$ between 200 and $400{ }^{\circ} \mathrm{C}$ due to water and surface $\mathrm{OH}$ groups being lost, followed by CMC degradation at 225 and $350^{\circ} \mathrm{C}$. They observed a second phase of weight loss of $\sim 4 \%$ between 700 and $800{ }^{\circ} \mathrm{C}$ attributed to the loss of carbonaceous remains of the CMC, and isotropic shrinkage of $\sim 5 \%$ between 200 and $400{ }^{\circ} \mathrm{C}$ and $\sim 7 \%$ between 800 and $900{ }^{\circ} \mathrm{C}$, reaching a total of $\sim 18 \%$ shrinkage at $1000{ }^{\circ} \mathrm{C}$ (Figure $7 \mathrm{~b}$ ). They also stated that there was an equal degree of shrinkage in both the struts and the voids. A glass transition was observed at $560{ }^{\circ} \mathrm{C}$ by DTA, followed by primary crystallization at $600^{\circ} \mathrm{C}$, a second glass transition at $910{ }^{\circ} \mathrm{C}$, and secondary crystallization at $850{ }^{\circ} \mathrm{C}$, with the glass melting at $1100{ }^{\circ} \mathrm{C}$, matching findings on bulk $45 \mathrm{~S} 5$ glass [61]. A very minor $\mathrm{Na}_{2} \mathrm{CO}_{3}$ phase was detected by XRD in the otherwise amorphous glass, and this persisted to $550{ }^{\circ} \mathrm{C}$, beyond which $\mathrm{Na}_{2} \mathrm{CaSi}_{2} \mathrm{O}_{6}$ crystallized as the major phase at $600{ }^{\circ} \mathrm{C}$. A secondary phase of $\mathrm{Na}_{2} \mathrm{Ca}_{4}\left(\mathrm{PO}_{4}\right)_{2} \mathrm{Si}_{2} \mathrm{O}_{4}$ crystallized at $850{ }^{\circ} \mathrm{C}$, with both $\mathrm{Na}_{2} \mathrm{CaSi}_{2} \mathrm{O}_{6}$ and $\mathrm{Na}_{2} \mathrm{Ca}_{4}\left(\mathrm{PO}_{4}\right)_{2} \mathrm{Si}_{2} \mathrm{O}_{4}$, then remaining at $1050{ }^{\circ} \mathrm{C}$.

The $45 \mathrm{~S} 5$ scaffold sintered at $1000{ }^{\circ} \mathrm{C}$ is shown in Figure 7 a. Upon heating to $500-1100{ }^{\circ} \mathrm{C} / 1 \mathrm{~h}$ to study their sintering behavior, the initial strut $(400 \mu \mathrm{m})$ and void $(200 \mu \mathrm{m})$ diameters began to significantly shrink above $500{ }^{\circ} \mathrm{C}$, decreasing 300 and $150 \mu \mathrm{m}$, respectively, at $\sim 1000{ }^{\circ} \mathrm{C}$ (Figure $7 \mathrm{~b}$ ) [48]. This printing paste had a solids loading of $45 \mathrm{vol} \%$ with an initial porosity of $\sim 80 \%, 50 \%$ being macroporosity from the voids and $30 \%$ being microporosity in the struts. This remained constant to 
$500{ }^{\circ} \mathrm{C}$, until a small initial loss of porosity occurred between 500 and $550{ }^{\circ} \mathrm{C}$ (the glass transition) followed by a continuous loss of porosity from $\sim 70 \%$ at $800{ }^{\circ} \mathrm{C}$ to $\sim 60 \%$ at $1000{ }^{\circ} \mathrm{C}$ (Figure $7 \mathrm{c}$ ). The bulk of this porosity was lost within the struts, and not in the macroporosity of the scaffold framework. Indeed, the surface of the struts appeared sealed at $1000^{\circ} \mathrm{C}$ as the intergranular phase was lost, and the $10 \%$ microporosity remaining in the struts was in the form of closed internal pores. This $80 \%$ and $70 \%$ total porosity at 550 and $800{ }^{\circ} \mathrm{C}$, respectively, was less than those compared to $45 \mathrm{~S} 5$ scaffolds made from other methods, but was still enough to allow bone regeneration and vascularization. The poor sinterability of $45 \mathrm{~S} 5$ is demonstrated by the $60 \%$ porosity remaining at $1000{ }^{\circ} \mathrm{C}$. The compressive strength of the sintered scaffolds was $\sim 2-5 \mathrm{MPa}$ at $600{ }^{\circ} \mathrm{C}, \sim 5 \mathrm{MPa}$ at $800{ }^{\circ} \mathrm{C}$, and $\sim 10 \mathrm{MPa}$ at $1000{ }^{\circ} \mathrm{C}$ (Figure 7d), within the range for cancellous bone, the authors claiming this to be up to $4000 \%$ greater than values seen in $45 \mathrm{~S} 5$ scaffolds made by foam replication and additive lithography methods.
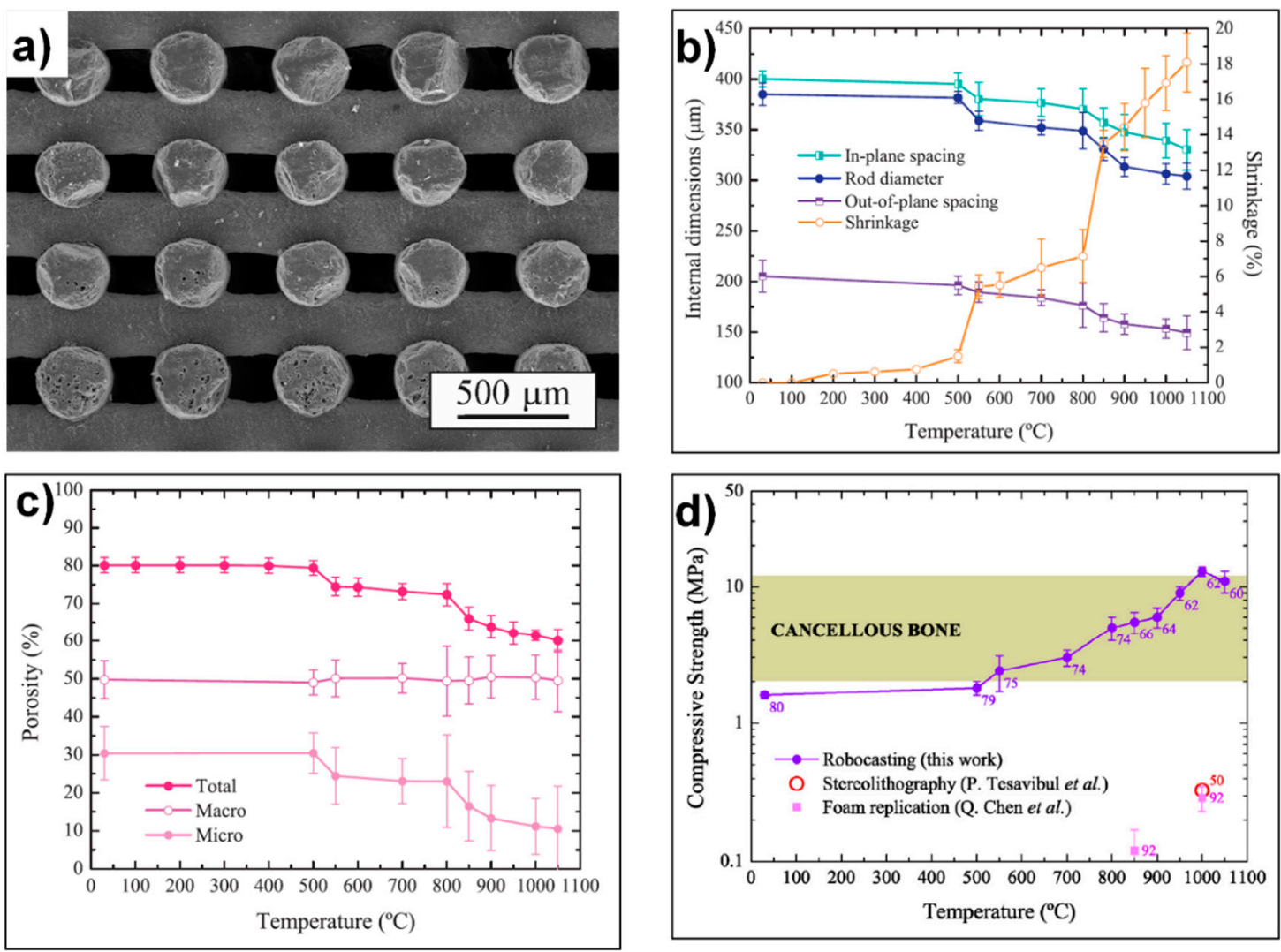

Figure 7. (a) Robocast $45 \mathrm{~S} 5$ scaffold sintered at $1000^{\circ} \mathrm{C} / 1 \mathrm{~h}$. (b) Shrinkage of the $45 \mathrm{~S} 5$ scaffold during sintering. (c) Change in porosity of the scaffold with sintering temperature. (d) Variation in compressive strength with sintering temperature, and comparison to other 45S5 scaffolds made by alternative additive manufacturing methods. Reproduced with permission from [48], Copyright Elsevier Ltd. 2014.

Robocast $45 \mathrm{~S} 5$ bioactive glass scaffolds were also reported in another paper by Eqtesadi et al., this time with a total of $35 \mathrm{vol} \%$ solids in the printing paste [62]. However, these were sintered under a flowing Ar atmosphere in a graphite furnace, first heated to $400{ }^{\circ} \mathrm{C} / 1 \mathrm{~h}$, and then to 550 or $1000{ }^{\circ} \mathrm{C} / 1 \mathrm{~h}$. Tetragonal and cylindrical lattice scaffolds with up to 50 layers high were created, and after sintering, the strut diameter was $\sim 400 \mu \mathrm{m}$ with rectangular $\sim 100-150 \times 250 \mu \mathrm{m}$ voids. A wide endotherm up to $200{ }^{\circ} \mathrm{C}$ was seen as free water and surface $\mathrm{OH}$ groups were lost, with an exothermic peak at $225^{\circ} \mathrm{C}$ as the CMC was removed in TGA/DTA measurements. The bioactive glass crystallized between 600 and $650{ }^{\circ} \mathrm{C}$ with a total weight loss of $\sim 10 \%$ at $800{ }^{\circ} \mathrm{C}$. Sintering in Ar had the effect of improving the density of the scaffolds, being $4 \%-5 \%$ more than those sintered in air. There was less bubbling and 
lower in-strut microporosity due to a decrease in the glass's viscosity in the Ar atmosphere, but some pores were still observed as a result of the glass bubbling.

XRD measurements of these amorphous Bioglass ${ }^{\circledR}$ scaffolds sintered in Ar at $550{ }^{\circ} \mathrm{C}$ indicated crystalline $\mathrm{Na}_{2} \mathrm{Ca}\left(\mathrm{CO}_{3}\right)_{2} \cdot 2 \mathrm{H}_{2} \mathrm{O}$, originating from the hydration of $\mathrm{Na}_{2} \mathrm{Ca}\left(\mathrm{CO}_{3}\right)_{2}$ crystals formed during heating in the graphite furnace and that became hydrated on standing at ambient temperature and humidity. Upon sintering at $1000{ }^{\circ} \mathrm{C}$ in $\mathrm{Ar}, \mathrm{Na}_{2} \mathrm{CaSi}_{2} \mathrm{O}_{6}$ was the major phase and $\mathrm{Na}_{2} \mathrm{Ca}_{4}\left(\mathrm{PO}_{4}\right)_{2} \mathrm{Si}_{2} \mathrm{O}_{4}$ the minor phase, due to the decomposition of $\mathrm{Na}_{2} \mathrm{Ca}\left(\mathrm{CO}_{3}\right)_{2}$. When sintered in air at $1000{ }^{\circ} \mathrm{C}$, $\mathrm{Na}_{2} \mathrm{CaSi}_{2} \mathrm{O}_{6}$ and $\mathrm{Na}_{2} \mathrm{Ca}_{4}\left(\mathrm{PO}_{4}\right)_{2} \mathrm{Si}_{2} \mathrm{O}_{4}$ were both observed, without previous $\mathrm{Na} 2 \mathrm{Ca}\left(\mathrm{CO}_{3}\right)_{2}$ formation. On sintering in Ar, the relative density of the scaffolds was $\sim 31 \%$ at $550{ }^{\circ} \mathrm{C}$ and $\sim 42.5 \%$ at $1000{ }^{\circ} \mathrm{C}$. Their compressive strength was $2.5 \mathrm{MPa}$ after heating at $550{ }^{\circ} \mathrm{C}$ in $\mathrm{Ar}$, at the bottom of the cancellous bone to range, and this increased to $\sim 12 \mathrm{MPa}$ when heated to $1000{ }^{\circ} \mathrm{C}$ in $\mathrm{Ar}$.

It should be noted that in this same paper [62], Eqtesadi et al. also produced composite scaffolds based on $45 \mathrm{~S} 5$ glass mixed with reduced graphene oxide additives. As these are not pure bioactive glass scaffolds, exhibited no significant improvements in mechanical properties over other $45 \mathrm{~S} 5$ scaffolds, and had no reported data for biocompatibility or bioactivity, we have not added them to the discussion here.

\section{Sol-Gel-Synthesized Bioactive Glass Robocast Scaffolds}

Due to its high sodium content, the excessive leaching of $\mathrm{Na}^{+}$from $45 \mathrm{~S} 5$ printing pastes, accompanied by an increase in $\mathrm{pH}$, causes problems in the creation of an efficient dispersion. Although this was partially overcome by the use of CMC as a single printing additive, the sintered 45S5 scaffolds still exhibited poor densification due to the narrow sintering window between the onset of crystallization and the first glass transition in $45 \mathrm{~S} 5$.

For this reason, a high-silica, low-sodium sol-gel-based bioactive glass (HSSGG) was developed by Ben-Arfa et al. for robocasting. Despite the potential advantages of bioactive sol-gel glasses, until recently, there had been insurmountable problems in formulating robocasting inks. Their high specific surface area and porous structure, the very features that are advantageous in terms of bioactivity, were also responsible for up-taking a significant portion of the dispersing liquid, adversely affecting printability. The first robocast sol-gel-synthesized bioactive glass scaffolds were reported by the authors in 2019 [24].

As discussed above, an in-depth investigation to understand the combined effects of porosity and particle/agglomerate size on the rheological properties of the suspensions prepared from sol-gel-derived bioactive glass powders was required [31]. Powder milling was found to be a crucial step in creating a printable sol-gel ink, with control of factors such as rotation speed and BPR, allowing the milling time of the sol-gel bioactive glass powders to be reduced to only $1 \mathrm{~h}$ using a simple mechanical mill. This work enabled the prediction of sol-gel glass ink printability for a complex quaternary system, and resulted in the successful printing of a scaffold from the high-silica sol-gel glass (HSSGG, composition $=64.4 \mathrm{wt} \% \mathrm{SiO}_{2}, 4.9 \mathrm{wt} \% \mathrm{Na}_{2} \mathrm{O}, 21.5 \mathrm{wt} \% \mathrm{CaO}$, and $9.1 \mathrm{wt} \% \mathrm{P}_{2} \mathrm{O}_{5}$ ) [24]. This was robocast from $\mathrm{a}$ paste with $40 \mathrm{vol} \%$ solids loading and the scaffolds were sintered at $800{ }^{\circ} \mathrm{C} / 2 \mathrm{~h}$ [24]. Three types of scaffold were produced with as-printed void widths of 300, 400, and $500 \mu \mathrm{m}$, and after sintering, the strut diameter was $383 \mu \mathrm{m}$. The cubic voids had shrunk to $\sim 270, \sim 370$, and $\sim 460 \mu \mathrm{m}$ wide after sintering (9.5\% shrinkage). The sintered HSSGG scaffold with an original void size of $300 \mu \mathrm{m}$ is shown in Figure $8 \mathrm{a}$. The total porosity of this scaffold was $46.7 \%$, close to the optimum $50 \%$ value, and much lower than that of $45 \mathrm{~S} 5$ scaffolds sintered at equivalent temperatures. This was achievable because, coupled with the low shrinkage, the sol-gel-derived glass was highly microporous, with an estimated microporosity of $\sim 36 \mathrm{vol} \%$ in the bioactive glass struts-this being a great advantage of the sol-gel process. The majority of these micropores were also shown to be open, not closed, which is relevant as open micropores play an important role in biological activity. 

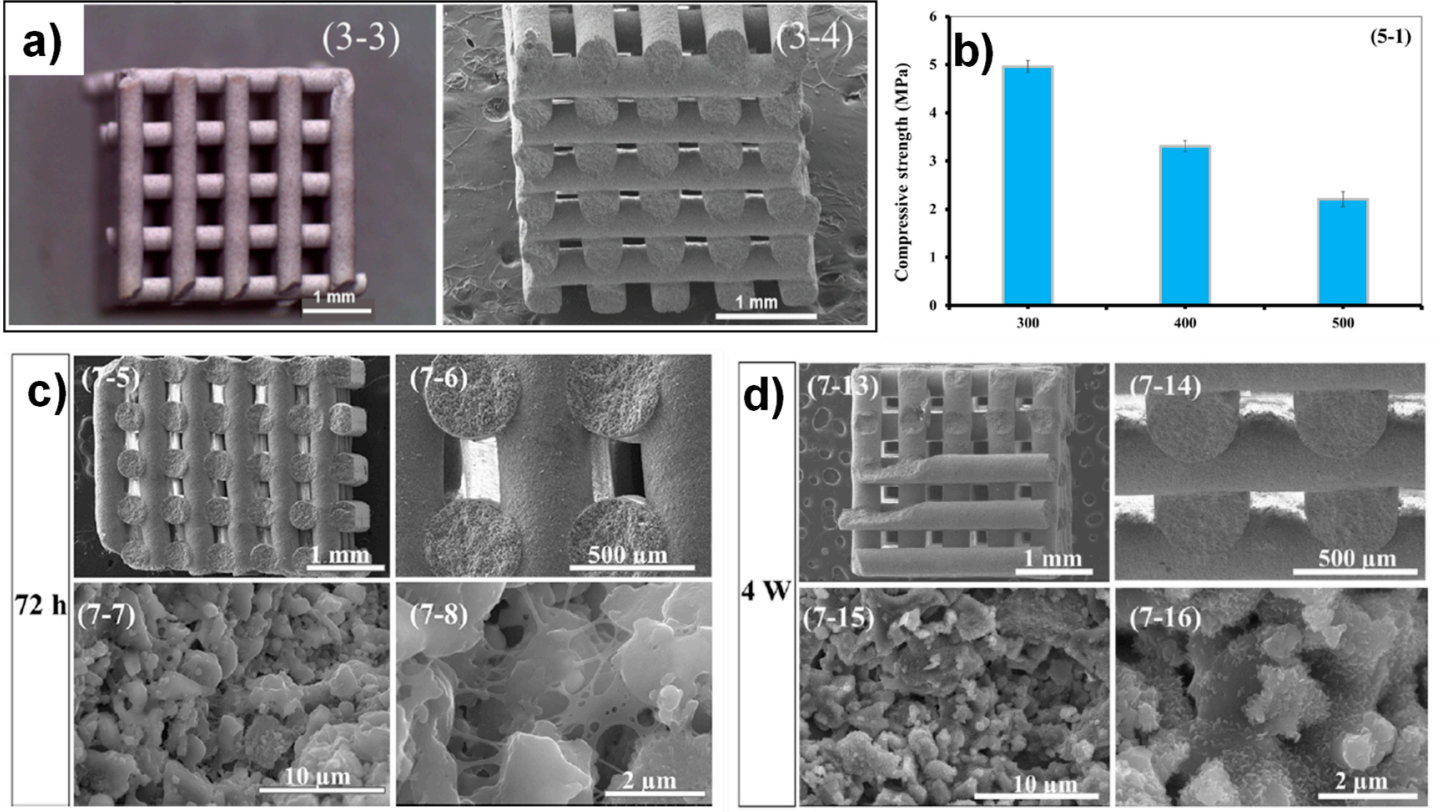

Figure 8. Robocast scaffolds of high-silica-content sol-gel bioactive glasses (HSSGG) sol-gel bioactive glass. (a) Optical and SEM images of scaffolds with $300 \mu \mathrm{m}$ as-printed void size, after sintering at 800 ${ }^{\circ} \mathrm{C} / 2 \mathrm{~h}$. (b) Compressive strength of the scaffolds with different void sizes (300, 400, and $500 \mu \mathrm{m}$ as printed) sintered at $800^{\circ} \mathrm{C} / 2 \mathrm{~h}$. Structural and morphological features of the scaffolds with $300 \mu \mathrm{m}$ printed void size after immersion in SBF for $72 \mathrm{~h}$ (c) and 4 weeks (d). Reproduced with permission from [24], Copyright Elsevier Ltd. 2018.

When heated to $550^{\circ} \mathrm{C}$, HSSGG was an amorphous but highly porous powder [37,38], this high degree of porosity preventing the preparation of printing pastes with over $25 \mathrm{vol} \%$ solids loading. To overcome this, the HSSGG powder was heat-treated at $800{ }^{\circ} \mathrm{C}$ (the same temperature was used to sinter the scaffolds), reducing the porosity of the glass powder and enabling a solids loading of $40 \mathrm{vol} \%$ in the paste, after milling of the powder. This higher heat treatment of the HSSGG powder resulted in the crystallization of three phases in the glass: Sodium calcium silicate, HAp, and cristobalite silica. This partial crystallization of the powder prior to the robocasting of the scaffold was also partly responsible for the high degree of microporosity remaining in the struts after sintering of the scaffold, as it limits the diffusion of the atoms.

The compressive strength of the HSSGG scaffolds is shown in Figure 8b, and the effects of void size can be clearly observed. It decreased from 5.0 MPa with a void size of $270 \mu \mathrm{m}$, to 3.3 and $2.2 \mathrm{MPa}$ with voids of 370 and $460 \mu \mathrm{m}$, respectively, as the macroporosity of the scaffold structure increases (values not published). All of these compressive strength values are in the region of cancellous bone, despite the inherent microporosity of the HSSGG scaffolds. The biocompatibility of the scaffolds was tested, and they were shown not to be cytotoxic toward MG63 osteoblast cells, with no significant difference between the scaffolds with different void sizes. They were also submersed in SBF for up to 4 weeks to test their bioactivity, and showed evidence of nano-HAp crystallization on the surface after $72 \mathrm{~h}$ (Figure 8c), with web-like filaments forming, probably consisting of a mixture of silica gel and nanoHAp. XRD patterns indicated an increase in intensity of peaks for both cristobalite and HAp with immersion, and HAp formation was also observed in FT-IR spectra. After 4 weeks immersion, both nano-HAp platelets/needles and micron-scale HAp grains were observed (Figure 8d), along with some dissolution of the bulk scaffold structure being observed.

In order to enhance the mechanical properties of these scaffolds, HSSGG was doped with 5 mol\% copper and lanthanum ions [23]. A previous sintering study utilizing Taguchi analysis had indicated that the addition of these ions could aid the sintering of HSSGG [63]. These scaffolds were also printed from pastes with $40 \mathrm{vol} \%$ solids loading, and sintered at $800{ }^{\circ} \mathrm{C} / 2 \mathrm{~h}$. The SEM images in 
Figure 9a-d show that while the La-doped scaffold did not appear to be significantly different, the $\mathrm{Cu}$-doped scaffold contained less microporosity and appeared more sintered. The total porosities of the $300 \mu \mathrm{m}$ void scaffolds had decreased with doping, to $42.6 \%$ and $37.8 \%$ respectively for La and Cu. High-magnification SEM images showed that there was a small increase in the formation of necks between glass particles with La addition in comparison to the parent glass, and a much greater increase with $\mathrm{Cu}$ addition. This demonstrated that both additives behaved as sintering aids for the glass, but with a much greater effect observed with the lower-melting-point copper additive acting as a flux agent. Due to this, a small increase in the compressive strength (7\%-18\%) accompanied the addition of La (Figure 9e). However, a much greater improvement in the compressive strength was observed with $\mathrm{Cu}$ addition, it being up to $221 \%$ greater than the HSSGG scaffolds, with compressive strength values of up to $14 \mathrm{MPa}$ for the scaffold with the smallest void dimensions (Figure 9e). As with the pure HSSGG glass, an increase in void size and macroporosity led to a decrease in compressive strength in all cases. This demonstrated that the compressive strength of the HSSGG scaffolds could be modified to cover the whole cancellous bone region by addition of copper as a sintering aid, without significantly impacting the printability of the ink. It was also demonstrated that the $\mathrm{La}^{3+}$ and $\mathrm{Cu}^{2+}$-doped HSSGG were still bioactive and fully biocompatible with various cell lines, including osteoblasts [64].
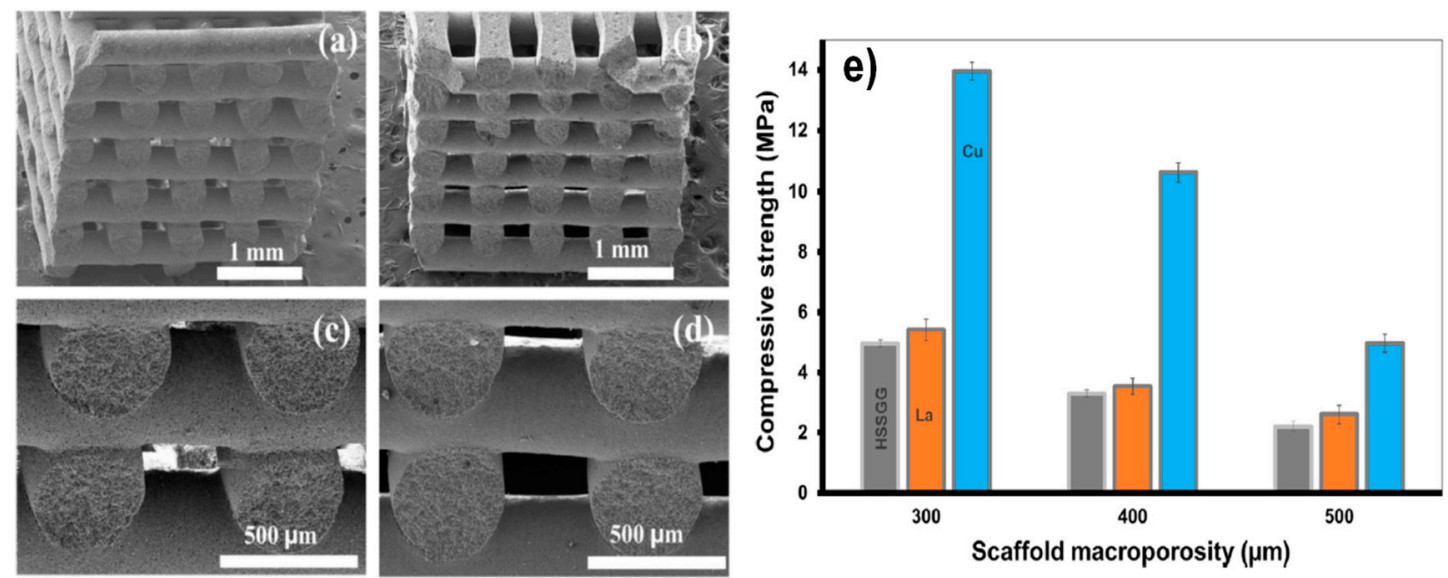

Figure 9. SEM images of robocast HSSGG sol-gel bioactive glass scaffolds, with $300 \mu \mathrm{m}$ as-printed void size and after sintering at $800{ }^{\circ} \mathrm{C} / 2 \mathrm{~h}$, with addition of $(\mathbf{a}, \mathbf{c}) 5 \mathrm{wt} \% \mathrm{Cu}^{2+}$ and $(\mathbf{b}, \mathrm{d}) 5 \mathrm{wt} \% \mathrm{La}^{3+}$. (e) Compressive strength of the scaffolds with different void sizes (300,400, and $500 \mu \mathrm{m}$ as printed) sintered at $800^{\circ} \mathrm{C} / 2 \mathrm{~h}$. Reproduced with permission from [23], Copyright Acta Materialia Inc. 2019.

\section{Comparison of Robocast Scaffolds from 45S5 Bioglass ${ }^{\circledR}$ and HSSGG Sol-Gel Bioactive Glass}

The properties of the $45 S 5$ Bioglass ${ }^{\circledR}$ robocast scaffolds and sol-gel HSSGG robocast scaffolds are compared in Table 1. These two glasses make for a good comparison as they have similar compressive strength in the unadulterated sintered scaffolds at similar temperatures, although the compressive strength of the HSSGG sol-gel glass could be improved with metallic dopants. It is immediately apparent that the range of compressive strength values covers the entire cancellous bone region ( 2-12 MPa). They were also both produced with a single organic additive to the printing paste (CMC). The main difference in composition between the two glasses is in silica and sodium content. 45S5 is a high-sodium-content glass, with $45 \mathrm{wt} \% \mathrm{SiO}_{2}$ and $24.5 \mathrm{wt} \% \mathrm{Na}_{2} \mathrm{O}$, whereas HSSGG contains $64.4 \mathrm{wt} \% \mathrm{SiO}_{2}$ and only $4.9 \mathrm{wt} \% \mathrm{Na}_{2} \mathrm{O}$. Due to problems with sintering, $45 \mathrm{~S} 5$ robocast scaffolds rarely achieve under $60 \%$ porosity, even when sintered at $1000^{\circ} \mathrm{C}$, and at the temperatures at which they remain amorphous $\left(<600^{\circ} \mathrm{C}\right)$, they can have up to $80 \%$ porosity. The lowest reported porosity is still a high $57.5 \%$, and that was only attained when sintered in an Ar atmosphere. The sol-gel-synthesized HSSGG scaffolds had surprisingly low total porosity values, all $<47 \%$, but nevertheless contained a high level of internal microporosity, an advantage of the sol-gel method and ideal for bioactivity, and compressive strength was also in the cancellous bone region. Dopants, especially $5 \mathrm{wt} \%$ copper, 
could further reduce the total porosity by acting as a sintering aid and encouraging shrinkage of the scaffold skeleton, increasing compressive strength to the top end of the cancellous bone range in a scaffold still only sintered at $800{ }^{\circ} \mathrm{C}$. To achieve similar values, $45 \mathrm{~S} 5$ needs to be sintered at $1000{ }^{\circ} \mathrm{C}$. It can also be observed in both 45 S5 and HSSGG scaffolds that the void dimensions have a significant effect on compressive strength when other factors are equal, with smaller-diameter voids resulting in significantly higher values. This allows for the opportunity to tune the compressive strength by merely adjusting the CAD-CAM model for the robocasting scaffold design, without changing other parameters such as glass or printing paste composition, strut dimension, or sintering temperature.

Table 1. Comparison of sol-gel robocast HSSGG bioactive glass scaffolds and 45S5 Bioglass ${ }^{\circledR}$ scaffolds robocast from glass powders produced by melt-quenching.

\begin{tabular}{|c|c|c|c|c|c|c|c|}
\hline $\begin{array}{c}\text { Glass } \\
\text { Synthesis }\end{array}$ & $\begin{array}{l}\text { Glass } \\
\text { Type }\end{array}$ & $\begin{array}{l}\text { Sintering } \\
\text { Temp. } \\
\left({ }^{\circ} \mathrm{C}\right)\end{array}$ & $\begin{array}{c}\text { Strut } \\
\text { Diameter } \\
(\mu \mathrm{m})\end{array}$ & $\begin{array}{l}\text { Void Size } \\
\qquad(\mu \mathrm{m})\end{array}$ & $\begin{array}{c}\text { Porosity } \\
(\%)\end{array}$ & $\begin{array}{l}\text { Compressive } \\
\text { Strength } \\
(\mathrm{MPa})\end{array}$ & Ref \\
\hline \multirow{6}{*}{$\begin{array}{c}\text { Melt- } \\
\text { quenching }\end{array}$} & \multirow{6}{*}{$\begin{array}{c}45 \mathrm{~S} 5 \\
\text { Bioglass }{ }^{\circledR}\end{array}$} & 600 & 400 & 200 & 80 & 2.5 & \multirow{3}{*}{ [48] } \\
\hline & & 800 & 360 & 180 & 72 & 5 & \\
\hline & & 1000 & 300 & 150 & 60 & 10 & \\
\hline & & 1000 & 200 & $100 \times 250$ & 63 & 13 & [15] \\
\hline & & 550 in $\mathrm{Ar}$ & $\sim 400$ & $\begin{array}{l}\sim 100-150 \\
\quad \times 250\end{array}$ & 69 & 2.5 & \multirow[t]{2}{*}{ [62] } \\
\hline & & 1000 in $\mathrm{Ar}$ & $\sim 400$ & $\begin{array}{l}\sim 100-150 \\
\quad \times 250\end{array}$ & 57.5 & 12 & \\
\hline \multirow{9}{*}{ Sol-gel } & \multirow{3}{*}{ HSSGG } & \multirow{3}{*}{800} & 383 & 270 & 46.7 & 5.0 & \multirow{3}{*}{ [24] } \\
\hline & & & 383 & 370 & - & 3.3 & \\
\hline & & & 383 & 460 & - & 2.2 & \\
\hline & \multirow{3}{*}{$\begin{array}{c}\text { HSSGG + } \\
5 \mathrm{wt} \% \mathrm{La}^{3+}\end{array}$} & \multirow{3}{*}{800} & 380 & 270 & 42.6 & 5.4 & \multirow{3}{*}{ [23] } \\
\hline & & & 380 & 370 & - & 3.5 & \\
\hline & & & 380 & 460 & - & 2.6 & \\
\hline & \multirow{3}{*}{$\begin{array}{c}\text { HSSGG }+ \\
5 \mathrm{wt}^{\circ} \\
\mathrm{Cu}^{2+}\end{array}$} & \multirow{3}{*}{800} & 380 & 270 & 37.8 & 13.9 & \multirow{3}{*}{ [23] } \\
\hline & & & 380 & 370 & - & 10.6 & \\
\hline & & & 380 & 460 & - & 4.9 & \\
\hline
\end{tabular}

The development of the first robocastable sol-gel-synthesized glasses is an important step, and may lead to glass scaffolds with an improved, greater microporosity in the strut structure and enhanced bioactivity as a result. The rapid sol-gel synthesis route, which is 100 times quicker than the fastest conventional sol-gel ageing bioactive glass synthesis methods, has also attracted a great deal of interest, and a patent for this is currently being applied for, hopefully to develop and commercialize this technology further.

Author Contributions: Conceptualization, B.A.E.B.-A. and R.C.P.; writing—original draft preparation, B.A.E.B.-A. and R.C.P.; writing-review and editing, B.A.E.B.-A. and R.C.P.; supervision, R.C.P.; funding acquisition, R.C.P. All authors have read and agree to the published version of the manuscript.

Funding: R. C. Pullar was funded by the FCT (Fundação para a Ciência e a Tecnologia, Portugal) grant number IF/00681/2015. This research was funded by, and this work was developed within the scope of, the project CICECO-Aveiro Institute of Materials, UIDB/50011/2020 \& UIDP/50011/2020, financed by national funds through the FCT/MEC and when appropriate co-financed by FEDER under the PT2020 Partnership Agreement.

Conflicts of Interest: The authors declare no conflict of interest. The funders had no role in the design of the study; in the collection, analyses, or interpretation of data; in the writing of the manuscript, or in the decision to publish the results. 


\section{References}

1. Bandyopadhyay, A.; Bose, S. Additive Manufacturing; CRC Press: Baton Rouge, LA, USA, 2016.

2. Cesarano, J.; Calvert, P. Method for freeforming objects with low-binder slurry. U.S. Patent 6,027,326; application filed 28 October 1997, application granted 22 February 2000,

3. Cesarano, J.; Segalman, R.; Calvert, P. Robocasting Provides Moldless Fabrication from Slurry Deposition. Ceram. Ind. 1998, 148, 94-102.

4. Smay, J.E.; Iii, J.C.; Lewis, J.A. Colloidal Inks for Directed Assembly of 3-D Periodic Structures. Langmuir 2002, 84, 5429-5437. [CrossRef]

5. Cesarano, J.; Dellinger, J.G.; Saavedra, M.P.; Gill, D.D.; Jamison, R.D.; Grosser, B.A.; Sinn-Hanlon, J.M.; Goldwasser, M.S. Customization of Load-Bearing Hydroxyapatite Lattice Scaffolds. Int. J. Appl. Ceram. Technol. 2005, 220, 212-220. [CrossRef]

6. Entezari, A.; Zhang, Z.; Chen, J.; Li, Q. Optimization of bone tissue scaffolds fabricated by robocasting technique. In Proceedings of the 11th World Congress on Structural and Multidisciplinary Optimization (WCSMO-11), Sydney, Australia, 7-12 June 2015; pp. 989-994.

7. Cesarano, J., III. A review of robocasting technology. Mater. Res. Soc. 1999, 542, 133-139. [CrossRef]

8. Nommeots-Nomm, A.; Lee, P.D.; Jones, J.R. Direct ink writing of highly bioactive glasses. J. Eur. Ceram. Soc. 2018, 38, 837-844. [CrossRef]

9. Tay, B.Y.; Evans, J.R.G.; Edirisinghe, M.J.; Tay, B.Y.; Evans, J.R.G.; Edirisinghe, M.J. Solid freeform fabrication of ceramics Solid freeform fabrication of ceramics. Int. Mater. Rev. 2003, 48, 341-370. [CrossRef]

10. Miranda, P.; Saiz, E.; Gryn, K.; Tomsia, A.P. Sintering and robocasting of beta-tricalcium phosphate scaffolds for orthopaedic applications. Acta Biomater. 2006, 2, 457-466. [CrossRef]

11. Fu, Q.; Saiz, E.; Tomsia, A.P. Bioinspired Strong and Highly Porous Glass Scaffolds. Adv. Funct. Mater. 2011, 21, 1058-1063. [CrossRef]

12. Deliormanl1, A.M.; Rahaman, M.N. Direct-write assembly of silicate and borate bioactive glass scaffolds for bone repair. J. Eur. Ceram. Soc. 2012, 32, 3637-3646. [CrossRef]

13. Dorj, B.; Park, J.; Kim, H. Robocasting chitosan/nanobioactive glass dual-pore structured scaffolds for bone engineering. Mater. Lett. 2012, 73, 119-122. [CrossRef]

14. Motealleh, A.; Eqtesadi, S.; Perera, F.H.; Ortiz, A.L.; Miranda, P.; Pajares, A.; Wendelbo, R. Reinforcing 13-93 bioglass scaffolds fabricated by robocasting and pressureless spark plasma sintering with graphene oxide. J. Mech. Behav. Biomed. Mater. 2019, 97, 108-116. [CrossRef] [PubMed]

15. Eqtesadi, S.; Motealleh, A.; Miranda, P.; Lemos, A.; Rebelo, A.; Ferreira, J.M.F. A simple recipe for direct writing complex $45 S 5$ Bioglass ${ }^{\circledR}$ 3D scaffolds. Mater. Lett. 2013, 93, 68-71. [CrossRef]

16. Hench, L.L.; Roki, N.; Fenn, M.B. Bioactive glasses: Importance of structure and properties in bone regeneration. J. Mol. Struct. 2014, 1073, 24-30. [CrossRef]

17. Hench, L.L. The story of Bioglass. J. Mater. Sci. Mater. Med. 2006, 17, 967-978. [CrossRef]

18. Rahaman, M.N.; Day, D.E.; Bal, B.S.; Fu, Q.; Jung, S.B.; Bonewald, L.F.; Tomsia, A.P. Bioactive glass in tissue engineering. Acta Biomater. 2011, 7, 2355-2373. [CrossRef]

19. Jones, J.R. Review of bioactive glass: From Hench to hybrids. Acta Biomater. 2013, 9, 4457-4486. [CrossRef]

20. Zheng, K.; Boccaccini, A.R. Sol-gel processing of bioactive glass nanoparticles: A review. Adv. Colloid Interface Sci. 2017, 249, 363-373. [CrossRef]

21. Saravanapavan, P.; Jones, J.R.; Pryce, R.S.; Hench, L.L. Bioactivity of gel-Glass powders in the $\mathrm{CaO}-\mathrm{SiO}_{2}$ system: A comparison with ternary $\left(\mathrm{CaO}-\mathrm{P}_{2} \mathrm{O}_{5}-\mathrm{SiO}_{2}\right)$ and quaternary glasses $\left(\mathrm{SiO}_{2}-\mathrm{CaO}-\mathrm{P}_{2} \mathrm{O}_{5}-\mathrm{Na}_{2} \mathrm{O}\right)$. J. Biomed. Mater. Res. A 2003, 66, 110-119. [CrossRef]

22. Li, R.; Clark, A.E.; Hench, L.L. An Investigation of Bioactive Glass Powders by Sol-Gel Processing. J. Appl. Biomater. 1991, 2, 231-239. [CrossRef]

23. Ben-Arfa, B.A.E.; Neto, S.; Salvado, I.M.M.; Pullar, R.C.; Ferreira, J.M.F. Robocasting of $\mathrm{Cu}^{2+} \& \mathrm{La}^{3+} \mathrm{doped}^{2}$ sol-Gel glass scaffolds with greatly enhanced mechanical properties: Compressive strength up to $14 \mathrm{MPa}$. Acta Biomater. 2019, 87, 265-272.

24. Ben-Arfa, B.A.E.; Neto, A.S.; Palamá, I.E.; Salvado, I.M.M.; Pullar, R.C.; Ferreira, J.M.F. Robocasting of ceramic glass scaffolds: Sol-gel glass, new horizons. J. Eur. Ceram. Soc. 2018, 39, 1625-1634. [CrossRef]

25. Ben-Arfa, B.A.E.; Salvado, M.M.; Ferreira, J.M.F.; Pullar, R.C. A hundred times faster: Novel, rapid sol-gel synthesis of without aging. Int. J. Appl. Glass Sci. 2016, 8, 337-343. [CrossRef] 
26. Hulbert, S.F.; Morrison, S.J.; Klawitter, J.J. Tissue reaction to three ceramics of porous and non-porous structures. J. Biomed. Mater. Res. 1972, 6, 347-374. [CrossRef]

27. Houmard, M.; Fu, Q.; Saiz, E.; Tomsia, A.P.; Division, M.S.; Berkeley, L. Sol-gel method to fabricate CaP scaffolds by robocasting for tissue engineering. J. Mater. Sci. Mater. Med. 2012, 23, 921-930. [CrossRef]

28. Saiz, E.; Gremillard, L.; Menendez, G.; Miranda, P.; Gryn, K.; Tomsia, A.P. Preparation of porous hydroxyapatite scaffolds. Mater. Sci. Eng. C 2007, 27, 546-550. [CrossRef]

29. Chan, B.P.; Leong, K.W. Scaffolding in tissue engineering: General approaches and tissue-specific considerations. Eur. Spine J. 2008, 17, S467-S479. [CrossRef]

30. O’Brien, F.J.; Christenson, L.; Mikos, A.G.; Gibbons, D.F.; Picciolo, G.L.E.E. Biomaterials \& scaffolds for tissue engineering. Mater. Today 2011, 14, 88-95.

31. Ben-Arfa, B.A.E.; Salvado, I.M.M.; Pullar, R.C.; Ferreira, J.M.F. Robocasting: Prediction of ink printability in solgel bioactive glass. J. Am. Ceram. Soc. 2019, 102, 1608-1618. [CrossRef]

32. Discher, D.E. Tissue cells feel and respond to the stiffness of their substrate. Science 2005, 310, 1139-1143. [CrossRef]

33. Engler, A.J.; Sen, S.; Sweeney, H.L.; Discher, D.E. Matrix Elasticity Directs Stem Cell Lineage Specification. Cell 2006, 126, 677-689. [CrossRef]

34. Karp, J.M.; Dalton, P.D.; Shoichet, M.S.; Cahn, F. Scaffolds for tissue engineering, clinical use of porous scaffolds for tissue engineering of skin. MRS Bull. 2003, 28, 301-306. [CrossRef]

35. Rabiee, S.M.; Nazparvar, N.; Azizian, M.; Vashaee, D.; Tayebi, L. Effect of ion substitution on properties of bioactive glasses: A review. Ceram. Int. 2015, 41, 7241-7251. [CrossRef]

36. Agarwal, R.; García, A.J. Biomaterial strategies for engineering implants for enhanced osseointegration and bone repair. Adv. Drug Deliv. Rev. 2015, 1, 53-62. [CrossRef]

37. Ben-Arfa, B.A.E.; Salvado, I.M.M.; Ferreira, J.M.F.; Pullar, R.C. Enhanced bioactivity of a rapidly-dried sol-gel derived quaternary bioglass. Mater. Sci. Eng. C 2018, 91, 36-43. [CrossRef]

38. Ben-Arfa, B.A.E.; Fernandes, H.R.; Salvado, I.M.M.; Ferreira, J.M.F.; Pullar, R.C. Synthesis and bioactivity assessment of high silica content quaternary glasses with Ca: P ratios of 1.5 and 1.67 , made by a rapid sol-gel process. J. Biomed. Mater. Part A 2017, 106A, 510-520. [CrossRef]

39. Kaur, G.; Pickrell, G.; Sriranganathan, N.; Kumar, V.; Homa, D. Review and the state of the art: Sol-gel and melt quenched bioactive glasses for tissue engineering. J. Biomed. Mater. Res. Part B Appl. Biomater. 2016, 104, 1248-1275. [CrossRef]

40. Hench, L.L. Bioceramics. J. Am. Ceram. Soc. 2005, 81, 1705-1728. [CrossRef]

41. Hench, L.L. Bioceramics: From Concept to Clinic. J. Am. Ceram. Soc. 1991, 74, 1487-1510. [CrossRef]

42. Karageorgiou, V.; Kaplan, D. Porosity of 3D biomaterial scaffolds and osteogenesis. Biomaterials 2005, 26, 5474-5491. [CrossRef]

43. Krell, A.; Klimke, J.; Hutzler, T. Advanced spinel and sub- $\mu \mathrm{m} \mathrm{Al}_{2} \mathrm{O}_{3}$ for transparent armour applications. J. Eur. Ceram. Soc. 2009, 29, 275-281. [CrossRef]

44. Miranda, P.; Pajares, A.; Saiz, E.; Tomsia, A.P.; Guiberteau, F. Mechanical properties of calcium phosphate scaffolds fabricated by robocasting. J. Biomed. Res. Part A 2008, 85, 218-227. [CrossRef]

45. Maazouz, Y.; Montufar, E.B.; Guillem-Marti, J.; Fleps, I.; Öhman, C.; Persson, C.; Ginebra, M.P. Robocasting of biomimetic hydroxyapatite scaffolds using self-setting inks. J. Mater. Chem. B 2014, 2, 5378-5386. [CrossRef]

46. Feilden, E.; Ferraro, C.; Zhang, Q.; García-Tuñón, E.; D’Elia, E.; Giuliani, F.; Vandeperre, L.; Saiz, E. 3D Printing Bioinspired Ceramic Composites. Sci. Rep. 2017, 7, 13759. [CrossRef]

47. Russias, J.; Saiz, E.; Deville, S.; Gryn, K.; Liu, G.; Nalla, R.K.; Tomsia, A.P. Fabrication and in vitro characterization of three- dimensional organic/inorganic scaffolds by robocasting. J. Biomed. Mater. Res. Part A 2006, 38, 434-445. [CrossRef]

48. Eqtesadi, S.; Motealleh, A.; Miranda, P.; Pajares, A.; Lemos, A.; Ferreira, J.M.F. Robocasting of $45 S 5$ bioactive glass scaffolds for bone tissue engineering. J. Eur. Ceram. Soc. 2014, 34, 107-118. [CrossRef]

49. Liu, X.; Rahaman, M.N.; Hilmas, G.E.; Bal, B.S. Mechanical properties of bioactive glass (13-93) scaffolds fabricated by robotic deposition for structural bone repair. Acta Biomater. 2013, 9, 7025-7034. [CrossRef]

50. Fung, Y.C. Biomechanics: Mechanical Properties of Living Tissues, 2nd ed.; Springer: New York, NY, USA, 1993.

51. Oliveira, M.L.L.; Chen, K.; Ferreira, J.M.F. Influence of the deagglomeration procedure on aqueous dispersion, slip casting and sintering of Si3N4-based ceramics. J. Eur. Ceram. Soc. 2002, 22, 1601-1607. [CrossRef] 
52. Loh, Z.H.; Samanta, A.K.; Heng, P.W.S. Overview of milling techniques for improving the solubility of poorly water-soluble drugs. Asian J. Pharm. Sci. 2014, 10, 255-274. [CrossRef]

53. Ben-Arfa, B.A.E.; Salvado, I.M.M.; Frade, J.R.; Pullar, R.C. Guidelines to adjust particle size distributions by wet comminution of a bioactive glass determined by Taguchi and multivariate analysis. Ceram. Int. 2019, 45, 3857-3863. [CrossRef]

54. Bentzon, M.D.; Andersen, L.O.; Goul, J.; Bodin, P.; Vase, P. Influence of the Powder Calcination Temperature on the Microstructure in $\mathrm{Bi}(\mathrm{Pb})-2223$ Tapes. IEEE Trans. Appl. Supercond. 1997, 7, 1411-1414. [CrossRef]

55. Ben-Arfa, B.A.E.; Salvado, I.M.M.; Pullar, R.C.; Ferreira, J.M.F. The influence of processing parameters on morphology and granulometry of a wet-milled sol-gel glass powder. Ceram. Int. 2018, 44, 12754-12762. [CrossRef]

56. Olhero, S.M.; Fernandes, H.R.; Marques, C.F.; Silva, B.C.G. Additive manufacturing of 3D porous alkali-free bioactive glass scaffolds for healthcare applications. J. Mater. Sci. Biomater. 2017, 52, 12079-12088. [CrossRef]

57. Eqtesadi, S.; Motealleh, A.; Pajares, A.; Miranda, P. Effect of milling media on processing and performance of 13-93 bioactive glass scaffolds fabricated by robocasting. Ceram. Int. 2015, 41, 1379-1389. [CrossRef]

58. Cesarano, J., III; King, B.H.; Denham, H.B. Recent Developments in Robocasting of Ceramics and Multimaterial Deposition. In Proceedings of the International Solid Freeform Fabrication Symposium, Austin, TX, USA, 10-12 August 1998; pp. 697-704.

59. Azzolini, A.; Sglavo, V.M.; Downs, J.A. Novel method for the identification of the maximum solid loading suitable for optimal extrusion of ceramic pastes. J. Adv. Ceram. 2014, 3, 7-16. [CrossRef]

60. Liu, D.M.; Tseng, W.J. Influence of solids loading on the green microstructure and sintering behaviour of ceramic injection mouldings. J. Mater. Sci. 1997, 32, 6475-6481. [CrossRef]

61. Boccaccini, A.R.; Chen, Q.; Lefebvre, L.; Gremillard, L.; Chevalier, J. Sintering, crystallisation and biodegradation behaviour of Bioglass ${ }^{\circledR}$-derived glass-ceramics. Faraday Discuss. 2007, 136, 27-44. [CrossRef]

62. Eqtesadi, S.; Motealleh, A.; Wendelbo, R.; Ortiz, A.L.; Miranda, P. Reinforcement with reduced graphene oxide of bioactive glass scaffolds fabricated by robocasting. J. Eur. Ceram. Soc. 2017, 37, 3695-3704. [CrossRef]

63. Ben-Arfa, B.A.E.; Salvado, I.M.M.; Ferreira, M.F.; Pullar, R.C. The effects of Cu2+ and La3+ doping on the sintering ability of sol-gel derived high silica glasses bioglass. Ceram. Int. 2019, 45, 10269-10278. [CrossRef]

64. Ben-Arfa, B.A.E.; Palamá, I.E.; Salvado, I.M.M.; Ferreira, M.; Pullar, R.C. Cytotoxicity and bioactivity assessments for $\mathrm{Cu}^{2+}$ and $\mathrm{La}^{3+}$ doped high-silica sol-gel derived bioglasses: The complex interplay between additive ions revealed. J. Biomed. Mater. Res. Part A 2019, 107, 2680-2693. [CrossRef] 